\title{
PROF. DR. ORHAN OĞUZ: O, BIR EKOL..
}

Hocamız Prof. Dr. Orhan Oğuz çokyönlü bịr insandır. Yarım asırlık çalışma hayatının kırk yılını aşan bir bölümü Türk Yüksek Öğreniminde, sekiz yıllık bir bölümü de Türk siyaset hayatında dolu dolu geçmiştir.

Eskişehir'de başlattığı ve kuruluşunu yaptığı ilk yüksek öğretim kurumunu 1960'ı yıllarda üniversiteye dönüștürmek için uğraş vermiş, Parlamento dışında yapılan çalışmalar sonuç getirmeyince siyasete girmiş; başarılı olmuş, amaçna ulaşarak Eskişsehir'de Anadolu Üniversitesinin kuruluşunu ve diğer üniversiter kurumların açımasını gerçekleştirmiştir. Bu arada üniversiter kurumların Anadolu'ya yayılmasında da geniş katkları olmuştur. Kısa sayılacak siyaset hayatında en üst düzeyde politika yaparak Milli Eğitim Bakanlığı yapmış, Avrupa Konseyi, Avrupa Topluluğu Karma Parlamento Grubu üyeliklerinde de bulunarak 1977 ylına gelmiş ve 1978 yilında yeniden akademik hayata dönmüştür. Bundan sonra Istanbul'daki Akademiyi Marmara Üniversitesine dönüştürme mücadelesine başlamış, onda da üstün bir başarı sergilemiş̧ir.

Biz, Hocamızın Rektörlüğünün son yıllarında kendilerini yakından tanıdık. Bu sebeple Hocamızla ilgili olarak burada yazdıklarımız O'nun verimli ve uzun akademik ve idarecilik hayatının sadece küçük bir bölümüne tanıklık etme iddiasındadır.

Prof. Dr. Orhan Oğuz, yaptıklarıyla, dünya görüşüyle ve kişiliğiyle başıı başına bir ekoldur. O, farklı bir kişiliğe sahiptir. O'nunla çalışanlar iyi bilir. Hocamız çok rahat bir insan. Karşısındakine güven verir. Gerginliğin en yüksek olduğu ortamlarda dahi şahsında taşıdığı bu rahatlatma duygusunu çevresine de yayar. Işlerde zorluk çıkarmaz, zorlukları yenmenin yollarını araştırır ve bulur da. Işi basite indirger. Karşısındakine güvenir ve güvendiğini de belli eder. Karşısındakine bir çeşit kendikendini sorumlu kılma duygusu aşılar. Yetki devreder. Işleri öyle yaptııı. Ama yetki devrederken de yetkinin sınırlarını çizer. Bunu belli etmez. Fark ettirmeden yetki delegasyonu yapar. Kararı bir bakıma işi yapacak kişiye aldırı gibi yapar. Sonunda işi yapacak kişi kendisinin karar aldığını sanır ve işi sahiplenir..

Hocamız karşısındakine değer verir. O'na güvenebilirsiniz. Başınız sıkıştığında sizi yüzüstü bırakmaz. O'nunla zorlukları aşmanın daima bir yolu vardır. O' maiyetini korur ve bunu belli eder.

Bu satırların yazarı, Üniversitemizin diğer bazı şansıı mensupları kadar Hocamızla uzun yıllar birlikte çalışamadı. Ama gene de kendisini şanslılar arasında sayar. 1988'den bu yana Avrupa Topluiuğu Enstitüsü içinde çeşitli sıfatlarla görev yaptı. O’nun zamanında idarecilik yaptı ve Senato'da bulunma onurunu taşıdı. 
Hocamız Rektör iken Göztepe Kampüsündeki Ofisi, AT Enstitüsü ile aynı binada idi. Bu O'na Enstitü faaliyetlerini yakından izleme imkanı sağladı. Her fırsatta Enstitü ile ilgilendi. O sırada Enstitünün Müdürü sayın Prof. Dr. Halûk Kabaalioğlu idi. Biz de yardımcısı idik. Sayın Kabaalioğlu bir yıl süreyle yurt dışına gidince Müdüre vekalet ettik ve bu süre içinde Hocamızı daha yakından tanıdık. 0 , hep teşvik etti ve yardım etti. Bunu bir örnekle belirtmek isteriz. Bir gün Ankara'nın da bilgisi dahilinde Batılı bir diplomatın Enstitüyü ziyaret etmesi ve bu arada bir konferans vermesi gerekli oldu. Biz kısa süre içinde konferansı tertipledik ama gerekli bir kalabalığı, uygun bir dinleyici kitlesini nasıl toplayacağımızı düşünürken Hocamız imdadımıza yetişti. O zamanlar Hocamız daha Góztepe kampüsüne gelmeden önce Dekanlar, Müdürler, işi olanlar haber alır önceden gelmeye başlardı. Hocamız bir toplantıya gittiğinde etrafında önemli sayıda üst düzey idareci olurdu. Bazen sevmeseler bile toplantıyı izlerlerdi. O toplantıya da Hocamız diğer işlerini bir kenara bırakarak etrafındakilerle beraber geldi ve güzel bir toplantı oldu. Demek istediğimiz, Hocamız ayrıntılara da çok önem verirdi.

Hocamı şimdi emekli. Ama O'nun odası ve masası hala eski yerinde bozulmadan duruyor. Zaman zaman Enstitüye gelir ve odasında oturur. Bir bakıma hiçbir şey değişmedi.

Hocamızın AT'a özel bir ilgisi vardır. Türkiye'nin geleceğini hep batıda aradı. Bunu sağlıyacak çabalara da katkıda bulundu. Bugünkü $A B$ doğmadan çok önce, 1960'larda Hocamız Avrupa Ekonomik Topluluğu ile ilgili önemli bir kitap yazmıştır. ldareciliği sırasında AT ile ilgili her gelişmeyi destekledi. Kısaca hem akademik bakımdan hem idari bakımdan O Avrupa ile bütünleşmemizden yana.

Üniversitemiz kendisi için bir Armağan çıkardığında katkıda bulunmaya karar verdik. Ancak biz yazıyı hazırlayıp verinceye kadar Armağan baskıya verilmişti ve yazımız elimizde kaldı. Armağan çıktı. Güzeldi, ama AB ile ilgili yeterli yazı yoktu. Bu, içimizi burktu ve kendimizi suçlu hissetmemize yol açtı. Bunun üzerine karar verdik, biz de Hocamız için karınca kararınca bir Armağan çıkaracaktık. Dergimizin son sayısını Hocamıza Armağan ettik. Yazılar ısmarlandı. Hazırlıklar yapıldı ve Hocamızdan izin aldık. Şimdi, Hocamıza kendi yöntemimizle teşekkür ediyoruz.

Evet, Prof. Oğuz emekli oldu. Ama O bir ekol. Marmara Üniversitesinde işlevini sürdürüyor. Çünkü ekoller kurucularını aşarlar ve daha sonra da varlıklarını devam ettirirler. Bu ülkenin Hocamız gibi insanlara ihtiyacı var. Kendisine sağlıklı ve uzun bir ömür diliyoruz.

Prof. Dr. Aslan Gündüz

AT Enstitüsü Müdürü 


\section{PROFESSOR ORHAN OĞUZ: A LIVING LEGEND}

Professor Orhan Oguz is a versatile person. He spent more than fourty years of his career of about half century in the area of higher education and about eight years in the politics.

He was the founder of the first higher education institution in Eskişehir, established in the 1960s, which he made considerable efforts to turn into a university. But his unremitting efforts failed, and he decided to run for the Parliament. He was as much successful in the politics and he reached his aims through political means by establishing Eskişehir Anadolu University as well as some other universitary institutions. Meanwhile he made considerable contributions to the expansion of universitary institutions in Anatolia. In his relatively short political career, he occupied high level political offices such as the Ministry of Education, and memberships to the Council of Europe and the Turkish-EU Joint Parliamentary Commission. His political career ended in 1977, and he returned to academic life in 1978 in Istanbul Academy of Economics and Administrative Sciences. In this period, he managed to transform the Academy into the now Marmara University, and he made equally great contributions to the development of Marmara University as well.

I personally came to know him closely towards the end of his presidency. For this reason, our words here would relate only towards a small period of his long and productive academic and administrative career.

Professor Oğuz is a living legend and a school in his own right, with his achievements, his world outlook and his personality. He has a distinct character. The people who have worked with him know this well. $\mathrm{He}$ is a very calm person. $\mathrm{He}$ inspires confidence in his counterpart. He radiates a feeling of tranquility to the people around him even in settings where tension is at its highest. in work, he does not raise difficulties, on the contrary he seeks for ways to overcome them and he indeed finds them. He simplifies the work. He trusts his colleagues and makes this clear to them. He inspires in them a sense of self-accountability. He delegates authority for the 
execution of the work. Yet, he draws the limits of the authority. He will not do this in clear words; he delegates the authority imperceptibly. He acts as if he is having the decision taken by the person liable to do the job. Finally, the person thinks that it was himself who has made the decision, and thus embraces the job.

Professor Oğuz can always be trusted. He never leaves you faced down when you are in trouble. With him there is always a way to hurdle the obstacles. He protects his staff and make this evident.

The author of these lines was able to work with Professor Oğuz as of 1988, where he has held offices at different levels in the European Community Institute. He had administrative duties under Professor Oğuz's time, and had the honour of being a member of the University Senate.

While Professor Oguz was the President, his office in Göztepe Campus was in the building where the EC Institute is located. This gave the President the opportunity of watching the activities of the Institute closely. He took every occasion to deal with the matters of the Institute. At that time, the Director of the Institute was Prof. Dr. Halûk Kabaalioğlu, and I was his deputy. When Prof. Kabaalioğlu went abroad for one year, I deputized for him. During this time I had the chance of knowing Prof. Oguz more closely. He was always supportive and helpful. I would like to illustrate with an example. Once, the Ministry of Foreign Affairs informed us that, a foreign diplomat was to visit the Institute and give a conference on EC issues. On a short notice, we were asked to make the necessary preparations for the conference, but it was difficult to find a venue and time to summon an audience suitable for for the occasion in terms of quality and quantity. Soon the President rushed to our help. In those days, the daily visits of the President to Göztepe were interesting, in the sense that Deans, Directors and other senior officials would closely follow him and they would gather in the Campus before he arrived there. In meetings he participated, he would bring with him a crowd of high-ranking executives and academics. Sometimes these people would participate in the meetings even though might not be their favourite, out of respect for the President. He came to our meeting too, by cancelling his other appointments, together with such a group of people, and it was a good meeting. In short, the President would attach importance to details.

Professor Oguz is retired now. However, his room and desk in our Institute are intact and always ready as for his use. From time to time, he comes to the Institute and spends some time in his room. In a way nothing has changed. 
Professor Oğuz has had a special interest in the EC. He has always seen Turkey's future in the West. He has contributed to the efforts aiming to ensure this. Long before the EU of today was born, in the 1960s he wrote an important book about the European Economic Community. During his administrative duties, he supported every positive development related to the EC. Briefly, as an academic and as an administrator, he has ardently supported our integration with the EC.

When our University decided to publish a book in honour of the President, I decided to make my own contribution. But by the time I prepared my text, the book had already gone to printing, and I was was left with the text. The book was published. It was a valuable book but did not contain enough writings about the EU. This had disburded me and my staff in that respect. Thereupon, we made the decision to publish another modest publication in honour of Professor Oğuz, our Founding President. We devoted the last issue of our Journal to Him. Articles were requested from various academics. Necessary arrangements were made and we received Professor Oğuz's permission. Now, we express our gratitude to him in our own way.

True, Professor Oğuz is retired now. However, he is a living school by himself whose function is resumed by Marmara University. We believe that schools surpass their founders and survive after them. This country need people like Professor Orhan Oğuz. We wish him a long and healthy life...

Professor Aslan Gündüz

Director of the EC Institute 